\title{
DAMPAK KEBIJAKAN ISBAT NIKAH TERHADAP PERKAWINAN SIRI DAN CAMPURAN DI KABUPATEN CIANJUR ${ }^{1}$
}

\author{
Cucu Solihah*, Yuyun Yulianah, Hilman Nur, Mumuh M. Rozi \\ Fakultas Hukum dan Pasca Sarjana Ilmu Hukum Universitas Suryakancana \\ Jl. Pasir Gede Raya Cianjur \\ cucusolihah2012@gmail.com
}

\begin{abstract}
Marriage isbat policy applies to marriages in the context of divorce settlement, loss of marriage certificate, doubts about whether a marriage is valid or not, and to marriages that occurred before the entry into force of Law Number 1 of 1974 also against marriages committed by those who do not have marriage obstacles according to Law Number 1 of 1974, but the policy is also used by married couples who marry by means of sirri and mixed marriages. The research method uses a juridical normative approach in the form of descriptive analysis. Data sources used are primary data and secondary data in the form of regulations that are relevant to research. The results showed an indication of the use of legal loopholes in marriage isbat policies by the public and foreign nationals in marrying Indonesian women in order to avoid marital administration requirements.
\end{abstract}

Keywords: Sirri Marriage; Legality; Administration; Validity

\begin{abstract}
Abstrak
Kebijakan isbat nikah berlaku terhadap perkawinan dalam rangka penyelesaian perceraian, hilangnya akta nikah, adanya keraguan tentang sah atau tidaknya salah satu syarat perkawinan, dan terhadap perkawinan yang terjadi sebelum berlakunya Undang-Undang No. 1 Tahun 1974 juga terhadap Perkawinan yang dilakukan oleh mereka yang tidak mempunyai halangan perkawinan menurut Undang-Undang No. 1 Tahun 1974, namun kebijakan tersebut juga dimanfaatkan oleh pasangan suami istri yang menikah dengan cara siri dan perkawinan campuran. Metode penelitian menggunakan pendekatan normatif yuridis berupa analisis deskriptif. Sumber data yang digunakan adalah data primer dan data sekunder berupa peraturan yang relevan dengan penelitian. Hasil penelitian menunjukkan adanya indikasi pemanfaatan celah hukum dari kebijakan isbat nikah oleh masyarakat dan warga Negara asing dalam menikahi wanita Indonesia guna menghindari syarat administrasi perkawinan.
\end{abstract}

Kata Kunci: Pernikahan Siri; Legalitas; Administrasi; Keabsahan

\footnotetext{
${ }^{1}$ Penelitian Dosen Fakultas Hukum Univeritas Suryakancana, dengan No SK: 22/Dek-FH/UNSUR/Kep/X/2018 dengan sumber dana bersumber dari Dana Penelitian Dosen Fakultas Hukum Tahun 2018.
} 


\section{A. Pendahuluan}

Perkawinan merupakan fitrah manusia, dan dalam pemenuhan kebutuhan fitrah tersebut tidak semua orang melaksanakannya dengan dan sesuai dengan ketentuan hukum yang berlaku. Fenomena yang terjadi di masyarakat banyak praktik perkawinan yang hanya memenuhi syarat syah dan rukun nikah menurut agama saja, hal tersebut dilakukan dalam rangka mencari kehalalan hubungan perkawinan dan menghindari syarat administrasi perkawinan.

Sementara itu, keabsahan perkawinan sebagaimana ketentuan Pasal 2 UndangUndang No. 1 Tahun 1974 tentang Perkawinan tidak hanya mencakup unsur agama dan kepercayaan saja melainkan terdapat juga ketentuan dimana setiap perkawinan dicatat menurut peraturan perundang-undangan yang berlaku, artinya secara subtansi Pasal 2 yang terdiri dari ayat 1 dan 2 merupakan syarat perkawinan sebagai satu kesatuan utuh atau bukan syarat alternatif melainkan menjadi syarat kumulatif.

Tujuan ideal perkawinan menurut ketentuan Pasal 1 Undang-Undang No. 1 Tahun 1974 tentang Perkawinan adalah dalam rangka membentuk keluarga yang bahagia dan kekal berdasarkan Ketuhanan Yang Maha Esa, jadi perkawinan merupakan "Perikatan Keagamaan" karena akibat hukumnya adalah mengikat pria dan wanita dalam suatu ikatan lahir dan bathin sebagai suami istri dengan tujuan yang suci dan mulia yang didasarkan atas Ketuhanan yang maha esa itu mempunyai hubungan yang erat sekali dengan agama/kerohanian, sehingga perkawinan bukan saja mempunyai unsur lahiriah/jasmaniah, tetapi juga unsur bathiniah/rohaniah (Syaifuddin, 2014).

Harapan suatu pernikahan dapat menjaga kemaslahatan sosial, di tengah gonjang ganjingnya kerusakan moral, pernikahan yang sah dan kuat pondasinya akan membentengi individu keluarga sehingga tidak mudah terpengaruh dengan penyakit-penyakit sosial yang berkembang di sekelilingnya. Dalam pandangan islam pernikahan bukan hanya sebagai media peluapan kecenderungan terhadap lawan jenis, tetapi diharapkan juga sebagai pilar penopang kehidupan bermasyarakat, sehingga apabila pernikahannya baik maka akan berimbas pula pada terwujudnya tatanan masyarakat yang baik (Hanna, 2013).

Membahas mengenai perkawinan memang menarik ditelaah sebagai wilayah pluralitas hukum, sesuai dengan konsep dan pendekatan pluralisme hukum dan agama. Perkawinan adalah wilayah sosial yang dihuni oleh lebih dari satu sistem hukum (Ashsubli, Undang-Undang Perkawinan dalam Pluralitas Hukum Agama ( Judicial Review Pasal Perkawinan Beda Agama), 2015). Demikian pula terhadap perkawinan yang dilakukan secara siri atau perkawinan campuran yang dilakukan oleh dua warga Negara yang berbeda memiliki ketentuan perkawinan sesuai pemahaman agama, adat dan juga ketentuan hukum negaranya masing-masing, meskipun dalam aturan hukum perkawinan Islam tidak membedakan status kewarganegaan sebagai penghalang suatu keabsahan perkawinan.

Perkawinan yang dilakukan dengan cara siri atau perkawinan campuran yang terjadi dibawah tangan, secara legalitas perkawinan jenis tersebut tidak tercatat di Kantor Urusan Agama tempat pasangan tersebut melangsungkan perkawinannya sehingga tidak mempunyai akta nikah.

Perkawinan siri dan perkawinan campuran antar dua warga negara yang berbeda mengandung unsur yang berkaitan dengan dapat atau tidaknya seseorang mempertanggungjawabkan perbuatan hukum yang dilakukannya, selain itu suatu perkawinan harus memenuhi persyaratan usia dimana kedua calon mempelai yang akan melangsungkan perkawinan telah memenuhi persyaratan usia supaya perkawinan tersebut dapat dilaksanakan berdasarkan Undang-Undang No. 1 Tahun 1994 Tentang Perkawinan yang menggambarkan kecakapan seseorang untuk bertindak dalam lalu lintas hukum, 
khususnya dalam bidang hukum perdata (Darmabrata, 2003).

Terhadap praktik perkawinan siri yang berakhir pada proses isbat nikah pada hakikatnya yang demikian itu termasuk wilayah sosial dimana masyarakat dihadapkan pada pilihan dan konsekwensi hukum untuk melaksanakan perkawinan secara terang-terangan atau sembunyisembunyi (siri), untuk melegalkan perkawinan atau cukup kehalalan secara agama saja, selama tidak ada kerugian dan permasalahan hukum yang dihadapi pasangan suami istri dan keluarganya.

Adapun terhadap pasangan suami istri yang telah melaksanakan perkawinan siri dengan kewarganegaraan yang sama atau dengan kewarganegaraan yang berbeda dan menghendaki adanya legalitas formal perkawinannya tersebut, maka hukum memberikan alternatif solusi, yakni dengan proses isbat nikah (penetapan keabsahan perkawinan) sebagaimana ketentuan Pasal 2 Undang-Undang No. 1 Tahun 1974 menyebutkan bahwa dalam hal perkawinan tidak dapat dibuktikan dengan akta nikah, dapat diajukan isbat nikahnya ke Pengadilan Agama.

Pada dasarnya masyarakat yang memanfaatkan sarana hukum isbat nikah, pada hakikatnya merupakan suatu fenomena fitrah kebutuhan dasar manusia untuk menikah dan adanya indikasi kesadaran dan kebutuhan perlindungan hukum masyarakat untuk melegalkan perkawinan. Dua faktor tersebut akan menarik untuk dikaji dari aspek tuntutan dan dampak hukumnya mengingat dampak dari isbat nikah tidak hanya dapat dilihat dari sisi positifnya dimana para pasangan suami istri dapat memiliki legalitas dan keabsahan perkawinannya berdasarkan hukum juga berdampak terhadap sisi negatifnya. Dengan banyaknya praktik perkawinan siri dan perkawinan campuran di masyarakat dan masyarakat akan dengan mudah memanfaatkan celah hukum isbat nikah pada saat terdapat potensi masalah hukum dari perkawinan siri dan perkawinan campuran, namun jika dianggap tidak berpotensi masalah hukum, maka perkawinan siri dan perkawinan campuran akan semakin menjamur sehingga beresiko terhadap sulitnya penegakan dan penertiban hukum perkawinan.

Suatu hal yang sangat ironis pada praktik perkawinan siri dan perkawinan campuran ialah adanya kesadaran dan kepastian bahwa perkawinan tanpa pencatatan oleh pegawai pencatat nikah akan beresiko secara hukum, dan mungkin saja hal tersebut disadari dan terpikirkan sebelumnya dan setelah perkawinan siri dan perkawinan campuran dilaksanakan.

Berpijak dari adanya kebutuhan akan legalitas perkawinan dari pasangan suami istri dan anak-anak hasil perkawinan juga menyangkut harta dan hak keperdataan lainnya dari suatu suatu perkawinan siri dan perkawinan di bawah tangan, maka perkara isbat nikah masih menjadi perkara yang sangat tinggi di Jawa Barat umumnya dan di Pengadilan Kabupaten Cianjur khususnya.

Terhitung sejak periode tahun 2015, 2016 dan 2017 data isbat nikah yang masuk ke pangadilan agama Cianjur mengalami peningkatan yang cukup signifikan, dan pada umumnya perkawinan siri menjadi latar belakang pengajuan isbat nikah selain itu juga tidak jarang ditemukan alasan masyarakat dalam rangka menghindari sistem administrasi dan biaya perkawinan yang lebih tinggi dibanding biaya perkara isbat nikah ke Pengadilan Agama. Latar belakang inilah yang merupakan urgensi dilakukannya penelitian ini, sekaligus menunjukkan kebaharuan dan state of the art dari hasil penelitian ini dibandingkan dengan penelitian-penelitian yang telah dilaksanakan sebelumnya.

Adapun tujuan penelitian ini terutama dalam rangka mengetahuilatar belakang perkawinan siri dan perkawinan campuran menempuh jalur isbat nikah dan mengetahui dampak hukum dari perkawinan siri dan perkawinan campuran yang mendapat legalitas hukum melalui isbat nikah.

\section{B. Metode Penelitian}

Penelitian ini menggunakan pendekatan normatif yuridis yang berupa analisis deskriptif. Sumber data yang digunakan adalah data primer yang berupa wawancara 
dengan pihak Pengadilan Agama Kelas I Kabupaten Cianjur. Data sekunder berupa peraturan perundang-undangan, seperti Undang-undang No. 1 Tahun 1974 tentang Perkawinan, Undang-undang Republik Indonesia No. 50 Tahun 2009 tentang Perubahan Kedua atas Undang-Undang No. 7 Tahun 1989 Pengadilan Agama, Peraturan Menteri Agama Republik Indonesia Nomor 11 Tahun 2007 tentang Pencatatan Nikah, dengan teknik pengumpulan data diambil dari Pengadilan Agama Kabupaten Cianjur dengan analisis datanya menggunakan data triangulasi.

Metode analisis dilakukan melalui proses interpretasi, yaitu mencoba menerobos dan menangkap makna dari data yang diperoleh, dan kemudian dilakukan evaluasi kritis dan menyajikan pandangan alternatif yang lebih lengkap serta sesuai. Metode ini dilakukan untuk menghasilkan analisis yang lebih komprehensif dalam memahami permasalahan.

\section{Hasil dan Pembahasan \\ 1. Asas Legalitas dan Kepastian Hukum dalam Perkawinan}

Dalam negara hukum, hukum ditempatkan sebagai aturan main dalam penyelenggaraan kehidupan berbangsa dan bernegara dengan tujuan hukum itu sendiri untuk menata masyarakat yang damai, adil dan bermakna. Artinya sasaran dari negara hukum adalah terciptanya kegiatan kenegaraan, pemerintahan dan kemasyarakatan yang bertumpu pada keadilan, kedamaian dan kemanfaatan dan kebermaknaan. Dalam negara hukum, eksistensi hukum dijadikan sebagai instrument dalam menata kehidupan kenegaraan, pemerintahan dan kemasyarakatan.

Peran strategis pemerintah dalam menata kehidupan kemasyarakatan adalah dengan lahirnya Undang-Undang No. 1
Tahun 1974 tentang Perkawinan. Embrio lahirnya undang-undang perkawinan, sebagai bentuk telah adanya keeragaman pengaturan tentang perkawinan bagi seluruh masyarakat di Indonesia, melalui undangundang perkawinan ini maka perkawinan tidak hanya sekedar ikatan keperdataan antara seorang laki-laki dan wanita melainkan lebih kepada sebagai ikatan lahir batin antara pria dan seorang wanita sebagai suami istri dengan tujuan membentuk keluarga atau rumah tangga yangbahagia dan kekal berdasarkan ketuhanan YME (Ashsubli, Undang-Undang Perkawinan dalam Pluralitas Hukum Agama ( judicial Review Pasal Perkawinan Beda Agama), 2015).

Perkara permohonan isbat nikah ke Pengadilan Agama didasarkan atas Pasal 49 ayat (2) yang menjelaskan bahwa yang dimaksud bidang perkawinan sebagaimana yang diatur dalam Undang-Undang Nomor 1 Tahun 1974 tentang Perkawinan antara lain meliputi penetapan tentang sahnya perkawinan terutama terhadap perkawinan yang terjadi sebelum tahun 1974, namun dalam praktik perkara isbat nikah juga dipergunakan guna melegalkan perkawinan yang terjadi setelah tahun 1974 dengan pertimbangan dan dasar hukum lainnya.

Perkara isbat nikah merupakan jawaban atas tuntutan masyarakat akan kebutuhan legalitas dan kepastian hukum perkawinan berdasarkan fakta-fakta dan keadaankeadaan yang menjadi tuntutan sosial, sehingga hukum jika dilihat dari segi sosiologis, hukum tidak lebih dari pencerminan realitas social (Marzuki, 2009).

Berikut akan dikemukakan cerminan realita sosial perkara isbat nikah yang masuk ke Pengadilan Agama Cianjur terhitung sejak 2015 sampai dengan 2017 dengan perimbangan data perkawinan yang terjadi sebelum dan sesudah tahun 1974. 
Tabel 1.

Daftar Perkara Pengajuan Isbat Nikah

(Sumber dari Pengadilan Agama Cianjur)

\begin{tabular}{cccc}
\hline Tahun & $\begin{array}{c}\text { Jumlah Pengajuan } \\
\text { Perkara }\end{array}$ & $\begin{array}{c}\text { Perkawinan Setelah } \\
\text { Tahun 1974 }\end{array}$ & $\begin{array}{c}\text { Perkawinan Sebelum } \\
\text { Tahun 1974 }\end{array}$ \\
\hline 2015 & 793 & 696 & 97 \\
2016 & 1607 & 1527 & 112 \\
2017 & 1807 & 1692 & 195 \\
\hline
\end{tabular}

Fenomena lain bahwa permohonan isbat nikah di Pengadilan Agama Cianjur menunjukkan peringkat teratas untuk jenis perkara permohonan. Menurut aplikasi yang dikeluarkan oleh Pengadilan Tinggi Agama Jawa Barat pada tahun 2017, Pengadilan Agama Cianjur menerima perkara sebanyak 5.017 (lima ribu tujuh belas) perkara. Dari jumlah tersebut perkara isbat nikah menyumbang perkara sebanyak 1.738 (seribu tujuh ratus tiga puluh delapan) perkara atau 34,46\% (Barat, 2018).

Terdapat fenomena yang menarik dari tingginya perkara permohonan isbat nikah di Pengadilan Agama Kabupaten Cianjur, dimana posisi masyarakat yang mengajukan permohonan isbat nikah dipengeruhi oleh budaya hukum dan perspektif masyarakat terhadap perkawinan dan proses isbat nikah. Lingkungan sangat mempengaruhi sikap dan perilaku masyarakat terhadap hukum. Bahkan situasi dan kondisi lingkungan tersebut sangat mempunyai dampak hampir dominan dalam memberikan warna dan budaya tertentu bagi kehidupan manusia selanjutnya, sifat manusia akan sangat terpengaruh oleh kondisi tersebut.

Terdapat karakteristik unik dari sikap hukum masyarakat terhadap perkawinan siri dan isbat nikah di Kabupaten Cianjur, tingginya tingkat permohonan isbat nikah dilatarbelakangi oleh kebutuhan legalitas hukum. Namun demikian, justru kemudahan proses melegalkan perkawinan siri melalaui isbat nikah menjadi alasan masyarakat melakukan nikah siri. Artinya masyarakat menganggap selama perkawinan siri tidak merugikan dan syah menurut agama maka masyarakat mengganggapnya sebagai suatu hal yang akan dilestarikan pelaksanaannya, dan pada saat kebutuhan akan legalitas hukum maka masyarakat memanfaatkan kebijakan hukum untuk menyelesaikan permasalahan perkawinan siri. Namun, hal ini bukanlah sebuah ukuran untuk menentukan sifat-sifat manusia, apakah itu baik atau buruk. Tidak dapat dipungkiri bahwa kondisi sosio-kultural masyarakat juga turut andil dalam menentukan perilaku baik buruknya manusia, tapi hal itu tidak menjadi barometer yang mutlak bagi perkembangan perilaku manusia (Maslikhah, 2015).

Lembaga pembentuk dan pengak hukum senantiasasa akan memandang hukum tertulis yang berlaku saat ini (hukum positif, ius constitututm) sebagai hukum yang efektif dan efiesien. Masyarakat di lain pihak akan berpandangan bahwa kebiasaan yang hidup dan berlaku di dalam kehidupan masyarakat (hukum kebiasaan, hukum tak tertulis) merupakan hukum yang efektif dan efisien. Dengan demikian, menurut pandangan masyarakat hukum tertulis itu efektif dan efisesin apabila subtansi dan pelaksanaannya sesuai dengan kebiasaan yang hidup di dalam masyarakat.di samping itu, masing-masing anggota masyarakat akan memberikan respon secara ekonomis terhadap hukum yang berlaku. Masingmasing anggota masyarakat akan memandang hukum positif sebagai hukum yang berlaku bagi dirinya apabia hukumtersebut memberikan manfaat kepada dirinya (Purwaka, Beberapa Pendekatan untuk Memahami Hukum ( Several Approacher for Understanding The Law), 2015). 


\section{Kedudukan dan Tujuan Isbat Nikah}

Isbat nikah berarti penetapan atas pernikahan seorang laki-laki dengan perempuan sebagai suami istri yang pelaksanaannya menggunakan hukum islam dan telah memenuhi syarat dan rukun nikah, namun pernikahan yang telah terjadi tidak dicatatkan kepada Pegawai Pencatat Nikah (PPN) Kantor Urusan Agama. Keadaan ini tidak sesuai dengan Pasal 5 Kompilasi Hukum Islam (KHI), (1) yang memberi norma bahwa perkawinan bagi masyarakat islam setiap perkawinan harus dicatat. (2) pencatatan perkawinan tersebut tersebut pada ayat (1) dilakukan oleh Pegawai Pencatat Nikah (PPN) sebagaimana yang diatur dalam Undang-Undang No. 22 Tahun 1946 jo Undang-Undang Nomor 32 Tahun 1954. Pegawai Pencatat Nikah (PPN) juga diatur didalam Pasal 2 Peraturan Menteri Agama Republik Indonesia Nomor 11 Tahun 2007 tentang Pencatatan Nikah.

Berdasarkan penjelasan tersebut diatas, pada asasnya isbat nikah terhadap perkawinan yang dilakukan setelah berlakunya Undang-Undang Nomor 1 Tahun 1974 tidak dapat dibenarkan. Namun demikian, berdasarkan Pasal 7 ayat (3) Inpres No. 1 Tahun 1991 tentang Kompilasi Hukum Islam (KHI), telah terjadi pergeseran penafsiran dengan membuka pintu lebih lebar terhadap pengajuan itsbat nikah sebelum atau sesudah tahun 1974. Demikian pula Keputusan Mahkamah Agung Republik Indonesia Nomor KMA/032/SK/2006 tentang Pedoman Tugas dan Administrasi Pengadilan disebutkan bahwa isbat nikah adalah pengesahan perkawinan yang telah dilangsungkan menurut syariat agama Islam, akan tetapi tidak dicatat oleh KUA atau PPN yang berwenang.

Selanjutnya dijelaskan sahnya suatu perkawinan berdasarkan Pasal 2 ayat (1) Undang-Undang No. 1 Tahun 1974, perkawinan adalah sah apabila dilakukan menurut hukum masing-masing agamanya dan kepercayaannya itu dan tiap-tiap perkawinan dicatat menurut perundangundangan yang berlaku, sedangkan bagi perkawinan yang tidak dapat dibuktikan dengan akta nikah karena perkawinannya tidak dicatatkan melalui Pegawai Pencatat Nikah, maka dapat diajukan isbat nikah. Isbat nikah sebagaimana yangdimaksud oleh Pasal 7 huruf (e) KHI adalah isbat nikah bagi pasangan suami isteri yang perkawinannya tidak/belum dilakukan pencatatansebagaimana yang dimaksud oleh Pasal 2 ayat (2) Undang-Undang No. 1 Tahun 1974.

Pasal 7 ayat (3) Kompilasi Hukum Islam juga menjelaskan, isbat nikah yang diajukan ke Pengadilan Agama terbatas mengenai hal-hal yang berkenaan dengan: adanya perkawinan dalam rangka penyelesaian perceraian; hilangnya akta nikah; adanya keraguan tentang sah atau tidaknya salah satu syarat perkawinan; adanya perkawinan yang terjadi sebelum berlakunya Undang-Undang No. 1 Tahun 1974 dan; Perkawinan yang dilakukan oleh mereka yang tidak mempunyai halangan perkawinan menurut Undang-Undang No. 1 Tahun 1974.

Produk hukum Islam, khususnya hukum perkawinan Islam Indonesia, sangat ditentukan oleh perspektif perumusnya dan seringkali dipengaruhi oleh berbagai kepentingan, baikyang bersifat spiritual maupun yang bersifat material. Dengankata lain, perumusan hukum sangat dipengaruhi oleh berbagai aspek, termasuk aspek ideologi dan sensitivitas gender. (Khoirul, 2015)

Kesadaran akan hukum agama dan keyakinan masing-masing warga negara bangsa Indonesia yaitu perkawinan harus dilakukan berdasarkan hukum agama dan kepercayaan masing-masing. Hal ini merupakan crusial point yang hampir tenggelam, di samping itu perkawinan harus memenuhi administrasi pemerintahan dalam bentuk pencatatan (akta nikah) (Nurudin, 2004).

Berdasarkan Kompilasi Hukum Islam tersebut bahwa pengajuan isbat nikah dapat terjadidengan beberapa kemungkinan yang antara lain ditegaskan dalam huruf (e) pasal tersebut. Bahwa isbat nikah dapat diajukan 
terhadap perkawinan yang dilakukan oleh mereka yang tidak mempunyai halangan perkawinan menurut Undang-Undang No. 1 Tahun 1974.

Konsekuensi logis dari kebijakan tersebut lebih menekankan pada pemenuhan aspek syarat syah suatu keabsahan perkawinan dan tidak adanya halangan perkawinan yang menyebabkan perkawinan batal demi hukum. Namun demikian, pertimbangan-pertimbangan pelaksanaan permohonan isbat nikah harus juga dilihat secara kasuistik, terutama terhadap permohonan isbat nikah terhadap perkawinan yang dilakukan pasca tahun 1974, dengan pertimbangan sepanjang perkawinan tersebut dilakukan berdasarkan ketentuan agama (Islam) serta tidak bertentangan dengan ketentuan perundangundangan yang berlaku, harus menjadi pertimbangan hakim dalam mengabulkan permohonan isbat nikah seperti indikasi adanya poligami tanpa prosedur (liar), perkawinan siri dengan perbedaan kewarganegaraan maka permohonan isbat nikah tersebut harus dapat dipertimbangkan kembali oleh hakim di Pengadilan Agama.

\section{Implikasi Hukum Isbat Nikah}

Dalam pandangan masyarakat, perkawinan merupakan tali ikatan yang melahirkan keluarga sebagai dasar kehidupan masyarakat dan negara. Guna mewujudkan kesejahteraan dan kebahagiaan masyarakat perlu adanya landasan yang kokoh dan kuat sebagai titik tolak pada masyarakat yang adil dan makmur (Asuan, Perlindungan hukum Terhadap Harta Perkawinan Dalam Perjanjian Perkawinan, 2016).

Akibat dari suatu perkawinan memiliki dimensi yang cukup luas antara lain sosial dan hukum, mulai pada saat perkawinan maupun setelah perkawinan. Hal ini dikarenakan dalam suatu perkawinan banyak hal yang akan terjadi maupun yang akan didapatkan, seperti masalah harta, dan keturunan (Asuan, Perlindungan Hukum Terhadap Harta Perkawinan Dalam Perjanjian Perkawinan, 2016).
Setiap penerapan hukum pasti memiliki dampak baik dampak positif maupun dampak negatif, terhadap subyek hukum yang terdiri dari pihak yang mengatur dan pihak yang diatur dampak langsung yang dapat dirasakan oleh para pihak yang mengatur dan atau yang diatur karena mempunyai kepentingan langsung dengan objek pengaturan sebaliknya dampak tidak langsung dirasakan oleh pihak yang mengatur dan atau yang diatur karena kepentingan kedua pihak tersebut tidak perkaitan langsung dengan objek pengaturan (Purwaka, Beberapa Pendekatan Untuk Memahami Hukum (Several Approaches for understanding The Law), 2015). Demikian pula terhadap kebijakan isbat nikah sebagai celah hukum dari perumusnya guna memberikan aspek perlindungan hukum khususnya terhadap lembaga perkawinannya, perempuan dan anak sebagai hasil dari perkawinan siri.

Hukum dapat dipahami dengan memperhatikan dampak yang ditimbulkan terhadap hubungan antara berbagai pihak dalam kehidupan bermasyarakat dan bagaimana respon atau tanggapan berbagai pihak tersebut terhadap dampak dari penerapan hukum. Respon atau tanggapan dari para pihak yang memperoleh dampak positif adalah tindakan mendukung (pro) penerapan hukum dan oleh karena itu para pihak tersebut akan berupaya meningkatkan dampak positif tersebut (Purwaka, Beberapa Pendekatan Untuk Memahami Hukum (Several Approaches For Understanding The Law), 2015).

Pemanfaatan kebijakan hukum dari para pasangan suami istri yang tidak mau melaksanakan perkawinan sesuai dengan prosedur peraturan perundang-undangan dengan melaksanakan prosedur permohonan isbat nikah merupakan upaya meningkatkan dampak positif hukum bagi masyarakat.

\section{Simpulan dan Saran}

Berdasarkan kajian dan analisis permasalahan yang dikaji, maka dapat disimpulkan bahwa latar belakang perkawinan siri dan perkawinan campuran 
menempuh jalur isbat nikah adalah dalam rangka mempermudah proses perkawinan dengan hanya melaksanakan ketentuan syarat sahnya suatu perkawinan. Jika suatu perkawinan siri dan perkawinan campuran tersebut terindikasi masalah hukum berupa kebutuhan akan legalitas dan perlindungan hukum terhadap hak keperdataan maka akan ditempuh dengan jalur isbat nikah. Oleh karenanya diperlukan penegakan hukum dalam hukum perkawinan sesuai dengan ketentuan Undang-Undang No. 1 Tahun 1974 tentang Perkawinan, dimana sahnya suatu perkawinan tidak hanya memenuhi rukun dan syarat perkawinan saja melainkan juga harus adanya syarat administratif berupa akta perkawinan. Diharapkan pemerintah menyempurnakan aturan hukum dalam bentuk peraturan pemerintah untuk mengatur lebih lanjut syarat dan ketentuan isbat nikah.

Dampak hukum dari perkawinan siri dan perkawinan campuran yang mendapat legalitas hukum melalui isbat nikah semakin memperbanyak praktik perkawinan siri dan perkawinan campuran baik antar warga negara yang sama ataupun dua kewarganegaraan yang berbeda berakibat fatal jika para penegak hukum tidak selektif mengkaji kasuistik perkawinan siri dan perkawinan campuran karena akan terjadi penyelundupan hukum Warga Negara Asing yang menikahi wanita Indonesia karena dengan mudahnya Warga Negara Asing memanfaatkan celah hukum melegalkan perkawinan siri dan perkawinan campurannya melalui isbat nikah.

\section{DAFTAR PUSTAKA}

Ashsubli, M. (2015). Undang-Undang Perkawinan dalam Pluralitas Hukum Agama ( judicial Review Pasal Perkawinan Beda Agama). Jurnal Cita Hukum, 290.

Ashsubli, M. (2015). Undang-Undang Perkawinan dalam Pluralitas Hukum Agama ( Judicial Review Pasal Perkawinan Beda Agama). Jurnal Cita Hukum , 290.
Asuan. (2016). Perlindungan hukum Terhadap Harta Perkawinan Dalam Perjanjian Perkawinan. Jurnal Solusi, 406.

Asuan. (2016). Perlindungan Hukum Terhadap Harta Perkawinan Dalam Perjanjian Perkawinan. Jurnal Solusi , 407.

Barat, P. T. (2018, Juli selasa). http://118.97.189.242:9000/pengawasa n_sipp/proses_stat. Retrieved September Rabu, 2018, from http://118.97.189.242:9000/pengawasan _sipp/proses_stat:

http://118.97.189.242:9000/pengawasan _sipp/proses_stat

Darmabrata, W. (2003). Tinjauan UndangUndang No. 1 Tahun 1991 Tentang Perkawinan Besera Peraturan Pelaksanaannya. Jakarta: Gitama Jaya.

Hanna, S. (2013). Nikah Dalam Perspektif Fikih dan Kemaslahatan Sosial. Jurnal Lex Jurnalica , 87.

Khoirul, M. (2015). Otoritas Perempuan Menolak Ruju dalam Pendekatan Gender dan Maslahah. PALASTREN , 107.

Marzuki, P. M. (2009). Pengantar Ilmu Hukum. Jakarta: Kencana Prenada Media Group.

Maslikhah. (2015). Pendidikan Islam Berkeadilan Gender, Menyoroti Pemikiran Muhammad Attiyah AlAbrashi. PALASTREN , 330.

Nurudin, A. (2004). Hukum Perdata Islam di Indonesia. Jakarta: Prenada.

Purwaka, T. H. (2015). Beberapa Pendekatan untuk Memahami Hukum ( Several Approacher for Understanding The Law). Jurnal Hukum dan Peradilan , 258.

Purwaka, T. H. (2015). Beberapa Pendekatan Untuk Memahami Hukum (Several Approaches for understanding The Law). Jurnal Hukum Dan Peradilan, 529. 
Purwaka, T. H. (2015). Beberapa Pendekatan Untuk Memahami Hukum (Several Approaches For Understanding The Law). Jurnal Hukum Dan
Peradilan, 531.

Syaifuddin, M. (2014). Hukum Perceraian. Jakarta: Sinar Grafika. 